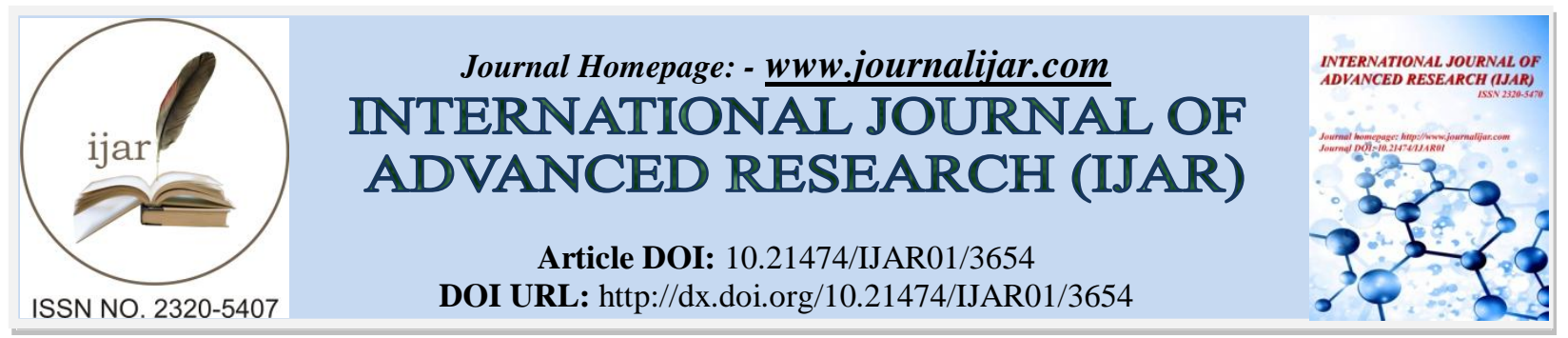

\title{
RESEARCH ARTICLE \\ SELECTED UNDERUTILIZED EDIBLE WILD FOOD PLANTS; THEIR ASSOCIATION WITH LEPIDOPTERON FAUNA AND ROLE IN TRIBAL LIVELIHOOD OF JAMBOORI PANCHAYAT SAMITI , ABU ROAD BLOCK IN SIROHI DISTRICT OF RAJASTHAN.
}

Sangeeta Tripathi and Meeta Sharma.

Arid Forest Research Institute, Jodhpur (Rajasthan)-342005.

\section{Manuscript Info}

Manuscript History

Received: 10 January 2017

Final Accepted: 03 February 2017

Published: March 2017

Key words:-

Underutilized trees, tribal livelihood

,lepidopteran fauna.

\section{Abstract}

Some plants (underutilized) are lesser-known plant species in terms of marketing and research, but well adapted to marginal and stress conditions. Their indigenous potential and ethno-botanical data are well known to people, whereas, commercial importance and market value is unknown to the public. A socio-economic survey was conducted in Jamboori Panchayat samiti of Abu Road area in Sirohi district of Rajasthan to assess the role of four edible underutilized food plants in tribal livelihood of Jamboori Panchayat Samiti. Findings reveals that the Garasia tribes inhibiting the area are unique in their ethno cultural heritage, far from the modern civilization and mostly depend on the forest and forest produce for their livelihood. These tribes are most backward and live in the interior forest. Livelihood systems in the study area are complex, based on primitive mode of agricultural practices. Common species in natural forest include Butea monosperma, Anogeissus latifolia, zizyphus spp., Azadirachta indica, Madhuca longifolia, Boswellia serrata, Manilkara hexandra, Diospyros melanoxylon, Phonix spp., Pithocellobium dulce, Annona squamosa, etc. and the main forest product exploitable commercially are Diospyros mealnoxylon (leaves), bamboo, firewood, gum and barks etc. but naturally occurring and underutilized species includes- $M$. hexandra, D. melanoxylon, M. dioica and P.dulce which are good source of vitamins proteins carbohydrates and minerals. Due to good source of proteins they are also found associated or infested by many insects and also serves as their host plants. In the present paper the association of lepidopteron fauna (Butterflies \& Moth) with some selected underutilized plant species with their role in tribal livelihood has been studied. The fruits were nutritionally rich and could be utilized for making by-products. Survey data reveals that if managed properly, these underutilized species could easily compete with commercial fruit-yielding species. Therefore, such fruit trees deserve priority action for conservation in natural forest stands and domestication in farmers' fields as a source of income generating activity.

Copy Right, IJAR, 2017,. All rights reserved. 


\section{Introduction:-}

Plants have been a good source of nutrition since the time immemorial and can be categorized as underutilized or neglected crops that occur in wild or are grown in local scale with their poorly addressed economic potential , confining them for mostly traditional and local use only. A considerable proportion of tribal population is still undernourished and the people living in remote areas cannot produce enough food grains to meet the yearly requirement. Therefore, a large share of such population meets its food requirement through non conventional means by consuming various wild plants and animal resources especially in periods of food scarcity (FAO, 2004; Balemie \& Kebebew ,2006). Wild food plants serve as alternative to staple food during periods of food deficit and are the valuable supplements for a nutritional balanced diet; one of the primary alternative source of income for many resource poor communities, and the source of species for domestication (Shrestha \& Dhillion ,2006). Wild fruits are important for the potential resources which could be utilized at the time of scarcity or during normal days or cultivated as a source of food material for an ever increasing population (Rashid et al, 2008). Bedsides, these trees and shrubs harbor butterflies, honey bee and other insects of economic importance. Being food source for many insects and animals; these underutilized plants serves as a host for caterpillars whereas other plants provide sustenance for butterflies. In turn, butterflies help to pollinate plants. Insects visit flowers to obtain food, usually in the form of pollen or nectar. (Sharma \& Sharma, 2013)

\section{Materials and Methods:-}

A preliminary survey was conducted to gather information on geographic area of villages, occupation pattern and socio-economic status of households. The interaction was held with State Forest Department, Sirohi, Zila Parishad and District Statistical Officer, Sirohi and Revenue Department, Abu Road. Similarly Key informant interviews were conducted with selected community leaders, traders and collectors at various study sites. For detailed socioeconomic survey $10 \%$ families in each study village was surveyed. Total 160 households were surveyed in four study villages of Jamboori Panchayat Samiti through semi-structurred and pre-tested questionnaire. Secondary data were collected from State Forest Department, Sirohi, Zila Parishad and District Statistical Officer, Sirohi and Revenue Department, Abu Road. Quantitative data was analyzed using SPSS where as qualitative data through coding and memoing (Punch, 2005). Results were analyzed for livelihood approach through strategic intervention for further implication. To find out the food resources of butterflies \& Moth in Jamboori Panchayat Samiti, Abu Road, a systematic study was carried out. The butterflies and moth were observed and identified with the help of various field guide (Evans, 1932).

\section{Result and Discussion:-}

Jamboori Panchayat Samiti of Abu Road area of Sirohi district in Rajasthan situated in $24.4641^{\circ} \mathrm{N}, 72.7718^{\circ} \mathrm{E}$ and consists of four tribal dominated villages viz. Jamboori, Meen, Taleti and Bosa. The main tribes of the region are Garasia but small population of Bhils- Gameti are also found. Their average literacy rate is $55.25 \%$ with male and female literacy as $69.98 \%$ and $39.73 \%$ respectively. Ratio of female per 1000 male is 940 . There are practically no basic amenities like safe drinking water, electricity, health services, roads and schools etc. These tribes reside in the interior parts of the forest and depend on the forest as their main source of livelihood. They also undertake agricultural activities during the monsoon season. $65 \%$ of the total area consists of forestland and only $6 \%$ land is under cultivation (Tripathi, 2016).

\section{Socio-economic status:-}

Most of the tribals of the region belongs to BPL category and percentage poverty ratio and intensity ranges from 54.49 -130.70.The Average distance of a village from Block Head quarter is $21 \mathrm{Km}$ and from the district head quarters is $72 \mathrm{Km}$. Hinduism is the main religion followed in the villages.Hand pump and wells are the most important sources of domestic use of water.Almost all the villages reported to have a primary school at the village level. The average distance of a secondary school from these villages is reported to be around 6 kms. Friends and relatives are the sources for availing credit by the households at the time of the need of credit. Ground water is available at a depth of around 120 feet and the quality of water is good and non brackish.

Average family size is 5.75 in Jamboori, 5.87 in Meen, 6.17 in Bosa and 9.51 in Taleti.Average land holdings per family is 1.39 beegha in Bosa, 1.61 beegha in Jamboori, 1.90 beegha in Taleti, and 2.00 beegha in Meen. Agriculture is mostly rainfed. Zea mays (Maize), Triticum aestivum (Wheat), Cajanus cajan (Tuar), Phaseolus vulgaris (Chanwla/Lobia), Cicer arientinum (Chana/gram), Vegetables, Ricinus Communis (Arandi/castor), Cyamopsis tetragonoloba (Gawar), Brassica juncea (Raida), Brassica campestric (Mustard) are some of the 
important crops that are cultivated in the study villages. Animal husbandry is also one of the important source of livelihood. Every family has one or two cows/buffaloes and 5-10 goats but the milk production from cows is very low i.e. 1-1.5 litres per day. Average Cattle owning families per village is $95.49 \%$ in Bosa, $96.51 \%$ in Jamboori, 98.03\% in Taleti and $100 \%$ in Meen. People usually do not sell milk and they use it for household consumption. However, the sale of goat and poultry fetches some money (about 1000-1500) every year. Women equally share the economy of a household and in some instances earns up to $75 \%$ of the income (Tripathi, 2016).

Fuelwood is the only source of cooking and is being extracted from nearby forest. On an average minimum and maximum amount of fuel-wood used by a household ranged $50-70 \mathrm{~kg} /$ household respectively and average collection of fuelwood from natural forest ranges between $50-70 \%$ percent and remaining requirement is fulfilled by crop residue and cowdung. The distance travelled by tribals for collection of fuelwood is less than $5 \mathrm{~km}$ in all the villages. The preferred species for fuelwood includes Manilkara hexandra, Butea monosperma, Anogeissus latifolia, Acacia nilotica, Tamarindus indica etc. whereas firewood of Diospyros melanoxylon, Madhuca indica, Annona squamosa, Feronia limonia etc. are generally not preferred as firewood by tribals.

The average income of households ranges from Rs. 20,000-25,000/- per annum. On average NTFPs contributes about $17 \%$ of the total income. However, the contribution ranges from $10-30 \%$ to different families. Among underutilized species maximum collection/family/annum is done by $P$. dulce followed by $D$. melanoxylon, $M$. dioca and $M$. hexandra (Table-2; Fig.1) whereas P.dulce is maximum underutilized species followed by $M$. hexandra, $D$. melanoxylon and $M$. dioica respectively (Table-2, Fig.-2). Honey collection is also done in Bosa. Tribals generally destroy the bee hive completely during honey collection. Intervention by NGO (Samarthak Samiti, Udaipur) / Agriculture Department etc. may help in non-destructive honey collection.Traders play an important role in NTFP selling. Most of them are local traders operating as middlemen simply collecting NTFP from village agents/shopkeepers and deliver in the nearby town. The tribals barter the daily NTFP collection for their daily use food items viz., pulses, jaggary, soap etc.All the underutilized NTFP species are nutritionally rich and some of them are good source of Vitamin A, B \& C (Misra \& Misra, 2016).

Table 1:- Socioeconomic status of the people in the study area.

\begin{tabular}{|l|l|l|l|l|l|}
\hline \multirow{2}{*}{ S. No. } & Study area and villages & Bosa & Jamboori & Meen & Taleti \\
\cline { 2 - 5 } & Variables & & & 385 \\
\hline 1 & Total number of households & 222 & 402 & 357 \\
\hline 2 & Number of households sampled & 40 & 40 & 40 & 40 \\
\hline 3 & Total population & 1261 & 2419 & 2175 & 2032 \\
\hline 4 & Average family size (persons per sampled household) & 6.17 & 5.75 & 5.87 & 9.51 \\
\hline 5 & Number of males & 677 & 1230 & 1094 & 1015 \\
\hline 6 & Number of females & 584 & 1189 & 1081 & $1017 *$ \\
\hline 7 & Sex ratio (females per thousand males) & 863 & 967 & 988 & 1002 \\
\hline 8 & Av. Child sex ratio & 753 & 895 & 934 & 971 \\
\hline 9 & Landholding per family (ha) & 1.39 & 1.61 & 2.00 & 1.90 \\
\hline 10 & Annual income per family (Indian Rupees) & & & & \\
\hline 11 & $* * \%$ Poverty ratio and intensity & 70.09 & 54.49 & 76.50 & 130.70 \\
\hline 12 & Average number of animals/household & 10 & 10 & 7 & 7 \\
\hline 13 & Livestock-owning families & 212 & 388 & 385 & 350 \\
\hline 14 & Average fuel wood consumed/household/day (kg) & 50.00 & 70.50 & 60.00 & 64.50 \\
\hline 15 & Families extracting fuelwood from forest (\%) & 50 & 70 & 55 & 60 \\
\hline 16 & Distance traveled for fuel wood collection (km) & $<5$ & $<5$ & $<5$ & $<5$ \\
\hline
\end{tabular}

\footnotetext{
**Poverty Ratio and Intensity=No of BPL households/ No of APL households x 100
} 
Table 2:- Average fruit yield/annum/family of four selected wild edible species and their utilization by tribals.

\begin{tabular}{|c|l|l|l|l|l|l|l|}
\hline $\begin{array}{l}\text { S. } \\
\text { No. }\end{array}$ & Species & $\begin{array}{l}\text { Local } \\
\text { name }\end{array}$ & Family & $\begin{array}{l}\text { Fruit } \\
\text { yield/annum } \\
(\mathbf{k g}) \quad \begin{array}{l}\text { Prevailing } \\
\text { M.E.E.) }\end{array}\end{array}$ & $\begin{array}{l}\text { \%arket } \\
\text { bate(Rs.) }\end{array}$ & $\begin{array}{l}\text { us } \\
\text { by } \\
\text { tribals } \\
\text { unutilized }\end{array}$ \\
\hline $\mathbf{1 .}$ & $\begin{array}{l}\text { Diospyros } \\
\text { melanoxylon }\end{array}$ & Tendu & Ebenaceae & $44.29 \pm 4.69$ & $15-30$ & 45 & 55 \\
\hline $\mathbf{2 .}$ & $\begin{array}{l}\text { Momordica } \\
\text { dioica }\end{array}$ & Kankoda & Cucurbitaceae & $42.02 \pm 6.90$ & $40-60$ & 60 & 40 \\
\hline $\mathbf{3 .}$ & $\begin{array}{l}\text { Manilkara } \\
\text { hexandra }\end{array}$ & Khirni & Sapotaceae & $36.75 \pm 3.36$ & $30-60$ & 35 & 65 \\
\hline $\mathbf{4 .}$ & $\begin{array}{l}\text { Pithocellobiu } \\
\text { m dulce }\end{array}$ & $\begin{array}{l}\text { Jungle } \\
\text { jalebi }\end{array}$ & Fabaceae & $50.98 \pm 6.69$ & $15-30$ & 25 & 75 \\
\hline
\end{tabular}

\section{Mean Fruit yield/annum/family (kg)}

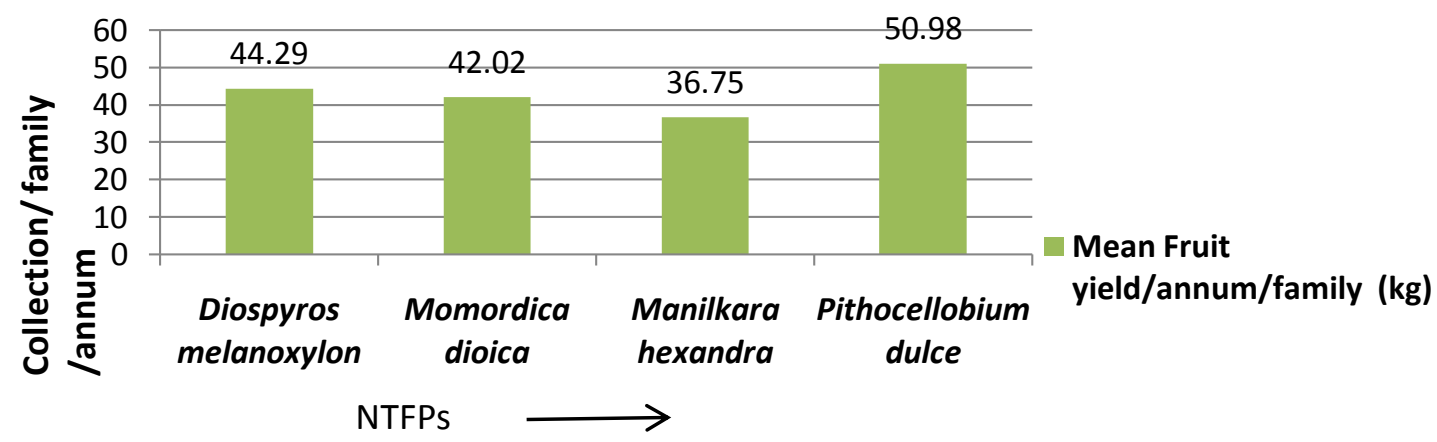

Fig 1:- Average fruit yield/annum/family of four selected wild edible species and their utilization.

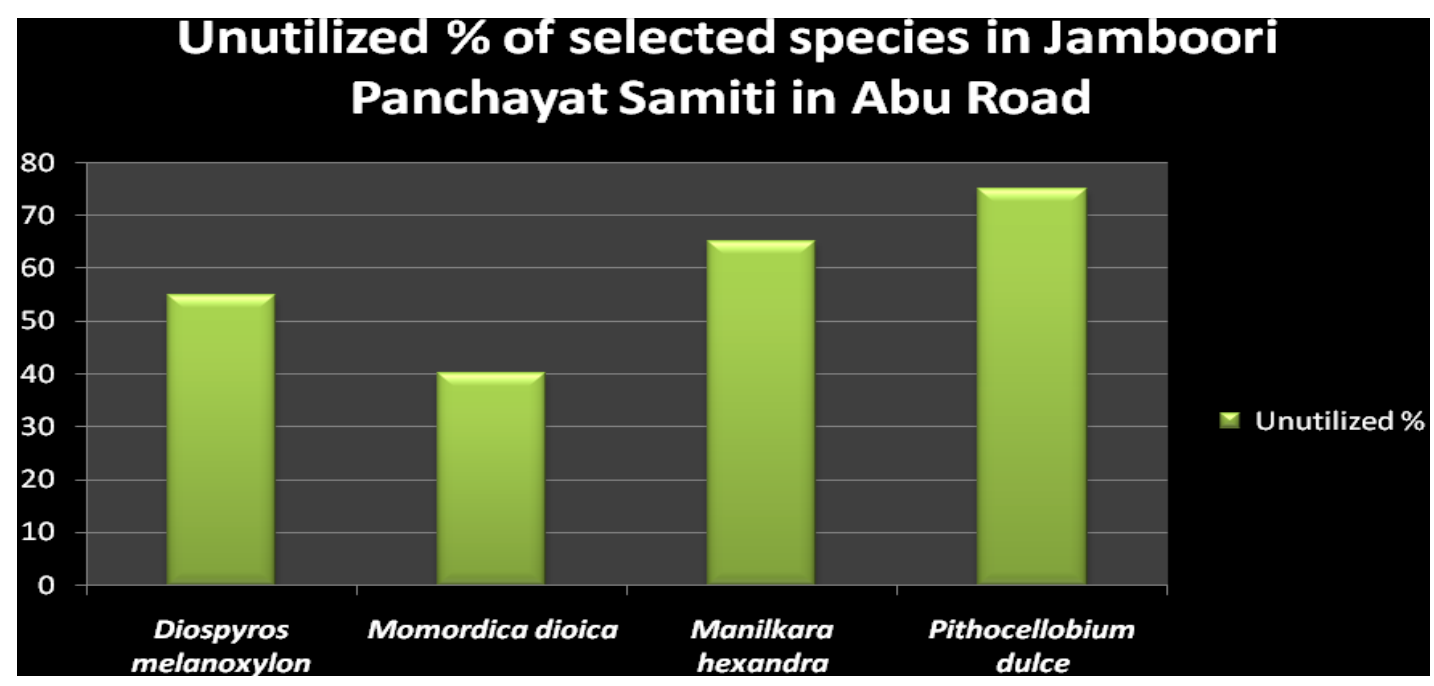

Fig 2:- Unutilized \% of selected species in study area 
Table 3:- Nutritional value of Important edible fruits collected wild by tribals.

\begin{tabular}{|c|c|c|c|c|c|c|c|}
\hline NTFP & Moisture content $\%$ & $\begin{array}{l}\text { Crude } \\
\text { protein }\end{array}$ & $\begin{array}{l}\text { Total } \\
\text { sugar } \\
\text { (mg/g) }\end{array}$ & $\begin{array}{l}\text { Total } \\
\text { lipid } \\
(\mathrm{mg} / \mathrm{g})\end{array}$ & $\begin{array}{l}\text { Vit. } \\
\text { B1 } \\
\text { (mg/g) }\end{array}$ & $\begin{array}{l}\text { Vit. C } \\
(\mathrm{mg} / \mathrm{g})\end{array}$ & Ref. \\
\hline Diospyros melanoxylon & 69.6 & $\begin{array}{l}8.64 \\
(\mathrm{mg} / \mathrm{g})\end{array}$ & $\begin{array}{l}266 \\
(\mathrm{mg} / \mathrm{g})\end{array}$ & $\begin{array}{l}.002 \\
(\mathrm{mg} / \mathrm{g})\end{array}$ & $\begin{array}{l}.004 \\
(\mathrm{mg} / \mathrm{g})\end{array}$ & $\begin{array}{l}.02 \\
(\mathrm{mg} / \mathrm{g})\end{array}$ & \multirow[t]{2}{*}{$\begin{array}{l}\text { (Misra and } \\
\text { Misra, 2016) }\end{array}$} \\
\hline Pithocellobium dulce & 78.6 & $\begin{array}{l}28.83 \\
(\mathrm{mg} / \mathrm{g})\end{array}$ & $\begin{array}{l}161.83 \\
(\mathrm{mg} / \mathrm{g})\end{array}$ & $\begin{array}{l}.006 \\
(\mathrm{mg} / \mathrm{g})\end{array}$ & $\begin{array}{l}.0022 \\
(\mathrm{mg} / \mathrm{g})\end{array}$ & $\begin{array}{l}1.08 \\
(\mathrm{mg} / \mathrm{g})\end{array}$ & \\
\hline Momordica dioica & 87.0 & $\begin{array}{l}52.06 \\
(\mathrm{~g} / 100 \\
\mathrm{gDW})\end{array}$ & $\begin{array}{l}14.58 \\
(\mathrm{~g} / 100 \\
\mathrm{gDW})\end{array}$ & $\begin{array}{l}4 \\
(\mathrm{~g} / 100 \\
\mathrm{gDW})\end{array}$ & ----- & $\begin{array}{ll}---- \\
--\end{array}$ & $\begin{array}{l}\text { (Salvi \& } \\
\text { Ketwa, 2015) }\end{array}$ \\
\hline Manilkara hexandra & $\begin{array}{ll}---- \\
-1\end{array}$ & $\begin{array}{l}0.48 \\
(\mathrm{~g} / 100 \mathrm{~g})\end{array}$ & ----- & ------ & ------ & $\begin{array}{l}15.67 \\
(\mathrm{mg} / 100 \mathrm{~g})\end{array}$ & (Jhawer,2014) \\
\hline
\end{tabular}

\section{Lepidopteron fauna associated with selected underutilized edible wild plant species}

Plant species:- Diospyros melanoxylon

\section{Grammodes geometrica Fabricius, 1775 (Lepidoptera: Noctuidae):-}

This is a beautiful moth colored in brown, black and cream. Fore wing consists of a distinct white band flanked on either side by broader black bands. The more distal one is also edged narrowly with white. Beyond this narrow white lining, an orangish-brown band is seen. Again an irregular black lining is present in discal area that goes upto apex. Costa is broadly grey-brown and none of the bands reach upto it. A black lined boundary in wavy manner is present beyond which fringes are clear in brown. The wild host of the moth were found to be Phyllanthus (Euphorbiaceae); Diospyros (Ebenaceae); Ricinus (Euphorbiaceae); 'grasses' (Gramineae); Polygonum (Polygonaceae); Zizyphus (Rhamnaceae).

\section{Grammodes stolida Fabricius, 1775 (Lepidoptera: Noctuidae):-}

This is a beautiful moth colored in brown, black and cream. Forewing consists of a distinct white band flanked on either side by broader black bands. The more distal one is also edged narrowly with white. Beyond this narrow white lining, an orangish-brown band is seen. Again an irregular black lining is present in discal area that goes upto apex. The moth was found to be polyphagous. The larvae feed on Rosaceae, Rhamnaceae (Zizyphus jujuba), and Zygophyllaceae (Tribulus).

Euthalia nais Forster, 1771 ((Lepidoptera: Nymphalidae):-

This butterfly species is generally seen in dry forested areas. It is beautiful orange colored with black boundary on terminals of both wings with hind wing boundary being broader and diffuse. The edges of wings are wavy, more clearly in HW. FW is shaped like a right angled triangle. The butterfly is fond of sunshine and is attracted by sap, over-ripe fruit and toddy. It feeds on Ebony, Diospyros melanoxylon (Ebenaceae) which grows in regions of light rainfall

Plant species:- Momordica dioica Roxb.

Pelopidas mathias Fabricius, 1798 (Lepidoptera:Hesperiidae):-

It is commonly known as small branded swift. Presence of brand has given it the common name Small branded swift. White spots are present on forewing. 2 separate cell spots, 1 in $1 \mathrm{~b}$ may/may not be present. 3 large quadrangular spots are present in discal area. 3 small spots lie in subapical region. Hind wing shows 2-3 inconspicuous spots. Ventral side shows similar spots on forewing while hind wing shows spots from 1 to 7 in a curved manner. 1 spot is visible in cell area. The common food plants are Momordica dioica and monocots.

Pelopidas conjuncta Herrich-Schaffer, 1869 (Lepidoptera:Hesperiidae):-

This is a small brown colored butterfly with white spots. Most of these spots appear to merge with each other. Their flight is very smmoth and powerful, therefore the name Conjoined swift is given to it. Ventral side is similar. Antennae are small, reaching upto end cell spots. Male has no brand. This butterfly for food depend on Rottboellia exaltata (Poaceae), Tridax procumbens (Asteraceae), Aerva lanata, Amaranthus gracilis (Amaranthaceae). 
Plant species:- Manilkara hexandra

Graphium sarpedon sarpedon Linnaeus, 1758 (Lepidoptera: Papilionidae):-

The blue bands on wings give it the common name Common bluebottle. Ground color of wings is brownish-black and the species is generally seen mud puddling. Hind wing is produced to end in a short tail or tooth. A pale blue or greenish blue discal band runs from inside apex of forewing and through cell of hind wing nearly to its dorsum. The adult Common Bluebottle feeds on nectar from a variety of flowering herbs. The larvae feed primarily on the leaves of trees in the families Myrtaceae, Sapotaceae and Rutaceae. Some other favorites are Polyalthia longifolia and Miliusa tomentosa (Annonaceae).

Graphium sarpedon teredon Felder and Felder, 1864 (Lepidoptera: Papilionidae):-

The blue bands on wings give it the common name Common bluebottle. Ground color of wings is brownish-black and the species is generally seen mud puddling. Hind wing is produced more compared to sarpedon to end in a short tail or elongated tooth. The discal bands are narrower compared to sarpedon on both the wings. The adult Common Bluebottle feeds on nectar from a variety of flowering herbs. The larvae feed primarily on the leaves of trees in the families Myrtaceae, Sapotaceae and Rutaceae. Some other favorites are Polyalthia longifolia and Miliusa tomentosa (Annonaceae).

Graphium agamemnon Agamemnon Linnaeus, 1758 (Lepidoptera: Papilionidae):-

The triangular shaped wings and green spots gives it the common name Green spotted triangle. The synonymous name is Zetides. It is a large tailed butterfly with green colored spots or bands all over the wings. The ground color is black with spots towards the base in band form, especially on hind wing. These large butterflies are very fond of Lantana camara (Verbenaceae), Ixora and Mussaenda.

\section{Graphium agamemnon menides Fruhstorfer, 1904 (Lepidoptera: Papilionidae):-}

The synonymous name is Zetides. It is a large tailed butterfly with green colored spots or bands all over the wings. The ground color is black with spots towards the base in band form, especially on hind wing. Females are similar but with a streak of greenish white along the dorsal margin on both dorsal and ventral sides. They are rarer compared to males. Thorax and abdomen on sides streaked with greenish grey. These large butterflies are very fond of Lantana camara (Verbenaceae), Ixora and Mussaenda.

Graphium nomius Esper, 1793 (Lepidoptera: Papilionidae):-

The presence of prominent spots on forewing and pointed tail on hindwing gives it the common name Spot swordtail. Wings are bluish white. Dorsal side shows black while ventral side shows brown bands. Forewing cell with 5 broad transverse black bands, a terminal black band occupies a terminal third of the wing and is traversed by a subterminal series of rounded spots of the ground color. The lower discal area is blackish. This butterfly also feed on Gmelina arborea.

Plant species:- Pithocellobium dulce

Charaxes athamas Drury,1773 (Lepidoptera: Nymphalidae):-

Their extremely swift and powerful flight on high trees gives it the common name Nawab. It is also known as Ergolis athamas. The ground color of wings is black characteristic to the genus. Broad yellowish or slightly green bands are present. They feed on various Fabaceae plants like Acacia, Albizia lebbeck, Caesalpinia sp., Delonix regia, Leucaena leucocephala, Grewia sp.

Charaxes solon Fabricius, 1793 (Lepidoptera: Nymphalidae):-

The royal black color of wings gives it the common name Black Rajah. It is also known as Charaxes fabius. It is a large sized butterfly with basal area and costal margin tinged blue.

\section{Hypolimnas bolina Linnaeus, 1758 (Lepidoptera: Nymphalidae):-}

The prominent egg shaped marking on forewing and hindwing gives it the common name Great Eggfly. Wings are completely black with forewing having a rounded white patch shaded blue outside covering interspaces 3,4,5. Another small similar patch lies in pre-apical area and a series of white dots in curvy fasion is visible in post discal area. These are attracted to Lantana camara (Verbenaceae), Bauhinia purpurea (Fabaceae) and Celosia argentea (Amaranthaceae). The caterpillar feeds on various tropical plants. Food plants of female are low growing species of Urticaceae- Pouzolzia zeylanica. 


\section{Danaus chrysippus Linnaeus, 1758(Lepidoptera: Danaidae):-}

It is the most common butterfly seen flying at low heights with low speed. It displays warning colors of black and orange which resembles like that of a tiger's body. Abdomen is yellowish while head and thorax are black. These butterflies could be seen at any time of the day. The female form of Danaid eggfly mimics this species.

\section{Eurema blanda Linnaeus, 1758 (Lepidoptera: Pieridae):-}

As the name suggests, three spots are present in the cell area of forewing on ventral side, therefore the name derived as Three Spot Yellow Grass. The adult butterfly are distinct yellow, small butterflies, with black marginal marks on the wings similar to Eurema hecabe. During the five larval instars, the yellow, hairless caterpillars successively defoliate the host tree. Pupae exuviae are often abundant on infested trees. The symptoms of Eurema blanda infestation are: skeletonized leaflets, during severe infestation host can be completely defoliated, often pupal exuviae abundant on skeletonized leaves, mostly young trees are affected.

\section{Ascalapha odorata Linnaeus, 1758 (Lepidoptera: Noctuidae):-}

Ascalapha odorata is a large bat-shaped, dark-colored nocturnal moth. The forewings are shaped like an obtuse triangle with a fairly long apex. Males can attain a wingspan of $16 \mathrm{~cm}$. The wings are mottled brown with hints of iridescent purple and pink, and, in females, crossed by a white bar. The forewing reniform spot is comma shaped, with dark filling except lighter bluish in the "tail," producing a convincing eyespot. Ascalapha odorata is a large bat-shaped, dark-colored nocturnal moth. The forewings are shaped like an obtuse triangle with a fairly long apex. Males can attain a wingspan of $16 \mathrm{~cm}$. The wings are mottled brown with hints of iridescent purple and pink, and, in females, crossed by a white bar. The forewing reniform spot is comma shaped, with dark filling except lighter bluish in the "tail," producing a convincing eyespot.

\section{Ascalapha odorata Linnaeus, 1758 (Lepidoptera: Noctuidae):-}

Ascalapha odorata is a large bat-shaped, dark-colored nocturnal moth. The forewings are shaped like an obtuse triangle with a fairly long apex. Males can attain a wingspan of $16 \mathrm{~cm}$. The wings are mottled brown with hints of iridescent purple and pink, and, in females, crossed by a white bar. The caterpillar feeds on woody Legumes such as Cassia, Acacia, Albizia, Prosopis, Pithecellobium and other Fabaceae species plants. Adults are highly vagile and migrate for hundreds of miles. They are primarily nocturnal and come to light and sugar baits, bananas. They also feed on Anacardiaceae and Moraceae plants.

\section{Conclusion:-}

The underutilized crops are species are used traditionally for food, fibers, fodder, oil or medicinal properties. They also have an underexploited potential to contribute to food security, nutrition, health, income generation and environmental services. Considering the importance of the crops as food, medicine and for industries, these underutilized crops can be exploited at the commercial level and their commercial potential will also provide important environmental services, as they are adapted to marginal soil and climatic conditions. Therefore, these underutilized crops have been included in world-wide plans of action after having successfully raised the interest of decision makers. The high nutritional qualities indicate that the cultivation and consumption of these crops may be helpful in overcoming the nutritional deficiencies predominant in many rural areas of the country and boost the socio-economic condition of the society.

On the other hand, butterflies are known to be the most fascinating creatures existing on this earth and have a great aesthetic value too. They are in close relation with these underutilized species in Jamboori Panchayat Samiti as they procure nectar from flowering plants to meet their energy requirements as well as they serve to be pollinators for various plant species which is the only means of their propagation. Hence, induction of these underutilized crops in agro-ecosystem for value addition products and their commercial exploitation through Village Forest Protection Committees /Self Help Groups as income generating activity will be beneficial for conservation of lepidopteron fauna of the region. 


\section{References:-}

1. Balemie K. and Kebebew, F. (2006): Ethnobotanical study of wild edible plants in Derashe and Kucha Districts; South Ethiopia; J. Ethnobiol Ethnomed; 2:53.

2. Evans, W.H.(1932). The identification of Indian Butterflies;. Bombay Natural History Society, Mumbai;454.

3. FAO (2004): The state of food insecurity in the world monitoring the progress towards the world food summit and millennium development goals. Annual Report, Rome.

4. Jhawer, M. (2014): The lesser known fruits with high nutritional value;www.medindia.net.

5. Misra, S. and Misra, K.M. (2016): Ethnobotanical and Nutritional Evaluation of Some Edible Fruit Plants of Southern Odisha, India; International Journal of Advances in Agricultural Science and Technology, 3 (1): 1-30

6. Punch KF. (2005). Introduction to social research, quantitative and qualitative approaches, Second Edition. Sage Publications Ltd.; 1 Oliver's Yard; 55 City Road, London, EC1Y 1SP.

7. Rashid A, Anand V. K, Serwar J. (2008): Less known wild edible plants used by the Gujjar tribe of District Rajouri, Jammu and Kashmir state- India. International journal of Botany. 4(2):219-224.

8. Salvi, Jyotsna and S. S. Katewa (2015): Nutritional Composition of Momordica dioica fruits: As a wild vegetable; J.Food Pharm.Sci. 3 (2015) 18-22

9. Sharma, Meeta and Sharma, N. (2013): Nectar resource use by Butterflies in Gir Wildlife Sanctuary, Sasan, Gujarat; Biological Forum-An International Journal; 5(2): 56-63.

10. Shrestha P.M. and Dhillon S. S. (2006): Diversity and traditional knowledge concerning wild food species in a locally managed forest in Nepal, Agroforest. Syst. : 55.

11. Tripathi, Sangeeta (2016): Customs, traditions, NTFP collection, marketing and key Issues of Garasia Tribes of Abu Road Block In Rajasthan, India; International Journal of Innovative Research and Advanced Studies (IJIRAS) ; 3 (8):113-119. 